\title{
THE
}
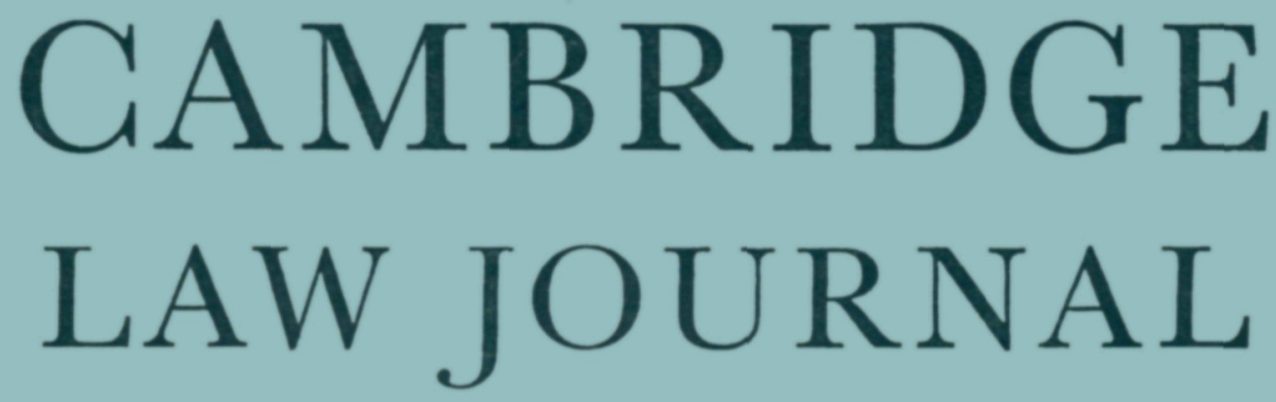

\section{April 1973}

Solicitors and the Law of Maintenance I590-1640

J. H. B A K E R

Some Structural Properties of Legal Decisions

s. c. coval and J. C. SMIth

Signature, Consent, and the Rule in L'Estrange v. Graucob J. R. SPENCER

Licences and Constructive Trusts-_"The Law is what it ought to be"

R. J. SMITH

For full contents see back of cover

\section{CAMBRIDGE UNIVERSITY PRESS}

FOR THE FACULTY OF LAW, UNIVERSITY OF CAMBRIDGE 


\section{THE GAMBRIDGE LAW JOURNAL}

EDITORIAL COMMITTEE

Professor C. J. Hamson, M.A., LL.M., Chairman and Treasurer

Professor Glanville L. Williams, Q.C., LL.D., F.B.A.

J. H. Baker, M.A., Book Review Editor

D. W. Bowett, M.A., LL.B., Note Editor

R. N. Gooderson, M.A., Note Editor

B. A. Hepple, M.A., LL.B., Note Editor

J. A. Jolowicz, M.A., Note Editor

M. J. Prichard, M.A., LL.B.

L. S. Sealy, Ph.D., Secretary

J. W. A. Thornely, M.A., Book Review Editor

D. G. T. Williams, M.A., LL.B., Note Editor

SUBSCRIPTIONS I 973

One volume of The Cambridge Law Journal is published each year. Each volume is in two parts, published in April and November. The subscription price of Volume 32 is $£ 4.00$ net ( $\$ \mathrm{I}_{3} .00$ in the USA and Canada), including postage, and is payable in advance. Single parts cost $£ 2.50$ net (\$8.0o in the USA and Canada) plus postage. Orders may be sent to any bookseller or subscription agent or to Cambridge University Press, P.O. Box 92, London NWI $2 \mathrm{DB}$, or in the USA and Canada to Cambridge University Press American Branch, 32 East 57th Street, New York, N.Y. 10022.

\section{BAGK VOLUMES}

Vols. I-I I (1921-53)

one volume of 3 parts every 3 years $\quad £ 8.5^{\circ}$ per volume (hardbound) $\AA^{2} .50$ per part (paper covers if available)

Vols. 12-29 (1954-I97I)

one volume of 2 parts every year

£5 per volume (hardbound)

fi.50 per part (paper covers

if available)

Vol. 30 (1972)

2 parts

$£ 7$ per volume (hardbound)

$£ 1.50$ per part (paper covers

if available)

Vol. 3 r (1972) Jubilee Issue

including Index

$\AA^{8}$ per volume (hardbound)
$£ 3.50$ per part (paper covers

if available)

\section{ADVERTISINO}

Details of advertising in the Journal may be obtained from Cambridge University Press. 


\title{
* Principles of Public International Law
}

\author{
Ian Brownlie, Fellow of Wadham College, Oxford
}

This second edition has been thoroughly revised to reflect recent developments in various areas of the law, including law of the sea, the admissibility of claims, and the law of treaties. New chapters deal with the law concerning diplomatic relations and State succession. The book provides a comprehensive account of the law of peace based upon the modem practice of States and international organizations and the jurisprudence of international tribunals. This is a textbook suitable for the student willing to tackle public international law on the same terms as other legal subjects. It also provides a convenient up-to-date work of reference for practitioners. Second edition $£ 8.50$ paper covers $£ 4$

\section{* A Text-Book of Jurisprudence}

\section{George Whitecross Paton}

Edited by G. W. Paton and David P. Derham, Vice-Chancellor, University of Melbourne

The first edition of Paton was published in 1946 and soon established itself as a standard students' textbook on jurisprudence. The fourth edition has been fully revised. Many recent developments which touch on the relationship of law to morals - homosexuality, obscenity, suicide, and abortion-are discussed, together with controversial economic aspects of modern legislation on such topics as restrictive trade practices and trade unions. Recent writing on criminology is studied, and many new cases and articles have been noted. Without losing its original character as an introduction for students the book is now very much concerned with the issues of the 1970 s. Fourth edition $£ 5$

\section{* An Introduction to Roman Legal and Constitutional History}

\section{Wolfgang Kunkel, Emeritus Professor of Roman Law, University of Munich}

Translated by J. M. Kelly, Professor of Jurisprudence and Roman Law, University College, Dublin

This book provides a short history of Roman Law and of its constitutional background; it incorporates in organic outline the results of recent research by the author and others in various areas of Roman political organization, Roman jurisprudence and criminal justice, and provincial government and the Digest. It should serve as a valuable introductory work for the study of general Roman history as well as of classical Roman law; and it contains an extensive bibliographical appendix in which the author critically describes the leading works in these fields. Second edition $£ 3.50$

\section{* Just published}

For further information about these or other Oxford books in this field please write to Oxford University Press (UPS), Ely House, 37 Dover Street, London WIX 4AH 


\section{Notaries Public in England}

in the thirteenth and fourteenth centuries

\section{R. C H E N E Y}

The activity of notaries public in medieval England has been underestimated. This Mediterranean institution became partially naturalized, and the author finds foreign notaries first in England in 1257 and 1258 . A native notariate, mainly concerned with church affairs, soon emerged. The background of notarial instruments in rhetoric and law is discussed, and in studying their diplomatic features notarial influences on non-notarial draftsman are observed. 6 folders $£ 5$

\section{Lord Kames and the Scotland of his Day}

\section{A N I M PSON ROSS}

Jurist, man of letters, improver; Henry Home of Kames, 1696-1782, was one of the leaders of the Scottish Enlightenment. This study draws on family papers, Kames's own writings, and contemporary and later accounts to bring to life a complex man and to relate him to an age of great social change in Scotland. 9 plates folding map $\mathbf{f} 6$

\section{The Advisory Jurisdiction of the International Court}

\section{DHA R A PRATA P}

This is the most comprehensive study yet attempted of the advisory jurisdiction of the International Court. It deals systematically with five aspects of this important feature of the Court: the evolution of the advisory procedure; the institution of advisory proceedings, by the competent bodies; the jurisdiction of the Court requests for advisory opinions; the procedure of the Court in dealing with requests; and the reception and effect of its advisory opinions. $£ 6$

\section{Studies in International Law}

\section{F. A. $\quad \mathrm{M} A \mathrm{~N} N$}

The first and longest essay in this collection, on The Doctrine of Jurisdiction, is probably the best account of the subject in any language. A specific theme connects the essays: the interrelationship of public international and municipal law. The author combines scholarship with practical experience, and this selection from his work makes available articles from legal works and periodicals from various countries, many of which are now difficult to find. $£ 7$ 


\title{
Oxford Essays in Jurisprudence
}

\section{Second Series}

\section{Edited by A. W. B. SI M P S ON}

This volume contains eleven essays dealing with central and controversial issues in jurisprudence. The emphasis this time is on legal theory, and the essays include individual and detailed explorations of such topies as Bentham's theory of legal rights, revolutions and the continuity of law, the nature and source of legal obligations and duties, the functions of law, and the relationship between positivist theories of law and common law systems. $£ 3 \cdot 50$

\section{Owners and Neighbours in Roman Law}

\begin{abstract}
A L A N RODGER
The idea of the extreme independence and sweeping powers of an owner under Roman Law has influenced thinking throughout the Civil Law world. Starting from the basis that the classical lawyers of Rome did not see ownership in such absolute terms, the author attempts to give a new explanation of certain servitudes of light, prospect, and water whose existence has puzzled scholars since the time of the Gloss. $£ 3.75$
\end{abstract}

\section{Indirect Rule and the Search for Justice}

\author{
Essays in East African Legal History \\ H. F. MOR R IS and JA MES S. REA D \\ These essays examine aspects of the search for justice which was a \\ recurrent theme during the colonial period. They trace the development \\ of official policies in East Africa, and the application of the doctrine of \\ indirect rule during its heyday. The authors have endeavoured \\ throughout to bridge the gap between history and law. Tables $£ 5 \cdot 50$
}

\section{A Source-Book on French Law}

\author{
Systems-Methods-Outlines of Contract \\ OT TO KAHN-FREUND, CLAUDINE LEVY and \\ BER N ARD RUDDEN
}

Recent happenings in Western Europe have forced the common law away from introspection. Now it must come to terms with Common Market Law. The system most available and approachable for the common lawyer is the French. These extracts, carefully selected from original sources, are linked by an English commentary, which explains difficulties and draws attention to common-law similarities and contrasts. $£ 3.75$ 